\title{
CLAIMS OF TRAVEL AGENTS IN CASE OF INSOLVENCY OF THE ORGANIZER OF TOURISM IN THE LIGHT OF EU DIRECTIVES
}

\section{PATRYCJA DOLNIAK}

University of Physical Education in Katowice, Sport and tourism management department, POLAND

e-mail: p.dolniak@awf.katowice.pl

RECEIVED
ACCEPTED
JEL
CLASSIFICATION

KEYWORDS

ABSTRACT
10 May 2018

20 September 2018

$\mathrm{K} 15, \mathrm{~K} 22, \mathrm{~K} 33, \mathrm{~K} 29, \mathrm{~K} 39$

insolvency, travel agent, directive, protection of customers' financial interests

The aim of the study is to analyse the protection scope of claims of insolvent travel agency's customers under EU law. The thesis assumes that the protection granted to the customers by the EU legislator covers all financial claims that may arise as a result of the failure of the tourist event in the consequence of the insolvency of the trader. At the same time, the tendency of the EU legislator is to deepen the scope of protection granted to the customers, through, among others, expanding the catalogue of entities benefiting from increased normative protection This extremely broadly defined by EU law standard of customer protection means that any incoherence to the rule, permitted by national legislation, will constitute an improper implementation of the Directive. This in turn can lead to a Member State's liability.

The topicality of the above mentioned problem increases the requirement for maximum harmonization of the legislation of Member States introduced by Directive 2015/2302, the implementation deadline for which is January 1,2018 . The aim of the EU legislature is to bring the rules of the Member States closer together so that customers can enjoy a homogeneous range of protection, regardless of where they purchased a tourist event.

\section{Introduction}

The purpose of this publication is to demonstrate that the protection afforded by EU travel insurance covers in principle all the costs incurred by the customer due to the failure of the tourist event in case of insolvency of entrepreneur. This almost absolute standard of protection means that any derogation from the rule allowed by the national legislation would imply wrong implementation of the directive. From this assumption, in turn, there is only 
a step to determine the liability of a Member State. Moreover, the protection of travellers, already large-scaled, is to be the subject of additional entity enhancement. According to the new directive, the entitlements previously granted to consumers may also in certain circumstances be granted to entrepreneurs.

\section{Method}

This paper, which is theoretical in nature, uses the method of analysing legal acts in the form of directives. Considerations concerning EU normative regulations have also been referred to the case law of the Court of Justice of the European Union (hereinafter referred to as the Court or the CJEU) and the statements made by the doctrine representatives.

\section{Results}

According to Art. 288 of the Treaty on the Functioning of the European Union (Official Journal C 326, 26/10/2012 P. 0001-0390), the directive is binding on the result, leaving the Member States free to choose the form and means of introducing it into the national legal order (Domańska, 2014, p. 24). Applying a legal act in the form of a directive means that legislation process will be conducted in two stages. The first is to set a target at EU level. In the second stage of legislative development, the objective of the directive is transposed into the national legal order by the adoption of the relevant legislation (Adam, Safjan, Tizzano, 2014, pp. 138-139; Galster, 2006, p. 138). In view of this "two-stage nature" of legislation, the Member States, when implementing the directive into national law, are required to take all necessary measures to ensure that the Directive is fully effective, in line with the aim pursued (Wróbel, 2005, pp. 45-47, judgement of 10.04.1984 in case 14/83 Von Colson and Kamann v. Land Nordrhein-Westfalen, European Court Reports (1984, p. 1891). The Directive which currently regulates the scope of protection of customers of tour operators is the Council Directive 90/314/EEC on package travel, package holidays and package tours of 13 June 1990 (Directive 90/314, OJ L, 23.6.1990). It was repealed by Directive 2015/2302 (Directive of 25.11.2015, OJ L 326/1), however, the date of implementation of the latter expires on January 1, 2018.

An entity who receives special protection is a consumer. Consumer is, according to Directive 90/314, the person who takes or agrees to take the package, or any person on whose behalf the principal contractor agrees to purchase the package or any person to whom the principal contractor or any of the other beneficiaries transfers the package, ie. 'the transferee' (Article 2 (4) of Directive 90/314). Regarding the content of the recited provision, there are doubts as to whether the concept of "consumer" under Directive 90/314 covers also entities acquiring a tourist event in connection with their economic activity (Gnela, 2008, p. 52). Anticipating further comments, it should be noted that in Directive 2015/2302 the EU legislator opted out of the notion of "consumer" in favour of the term "traveller" arguing that the terminological change was necessary in order to cover with the consumer protection also certain entrepreneurs. Accordingly, the author's assessment is that Directive 90/314 does not cover entities purchasing a tourist event in connection with their business activities in the field in question.

The importance of protecting the financial interests of consumers has already been emphasised by the preamble. According to its assumptions, if the contract is not fulfilled, or if the organizer does not expect to be able to fulfill it in whole or in part, both for consumers and for the tourist events sector, it would be beneficial to place on the organizers and/ or retailers the obligation to properly document financial collateral in the event of their insolvency (Stefanicki, 2014). The purpose set out in the preamble is to implement Art. 7 of the Directive (Kolasiński, 2008, 
pp. 251-252). According to its content, in the event of his insolvency, the organizer and/or retailer who is a party to the contract should provide sufficient collateral to allow the refund of the overpayment and the return of the consumer from the trip (Dolniak, 2017, pp. 26-27; Nesterowicz, p. 24; Walczak, 2007, p. 160; Cybula 2006, p. 137; Cybula, 2005, source: Lex; Wanat-Połeć, Sordyl, 2015, pp. 636-637).

Correct interpretation of art. Article 7 of Directive $90 / 314$ has been the subject of numerous judgments of the CJEU. The conclusion that can be drawn from this is that a client of an insolvent entrepreneur should not incur any costs associated with not completing a tour or a part thereof. If these costs were incurred, they should be returned in full. Historically, the first judgement on the scope of customer claims is the CJEU judgement in Dillenkofer case (Joined Cases C-178/94, C-179/94, C-188/94, C-189/94 and C-190/94, 1996, Reports of Cases 1996 I-04845; Sekuła-Leleno, 2017, p. 130; Thorson, 2016, p. 233). The Court held that Art. 7 grants the entities individual rights to pursue, in the event of the insolvency of the organizer, the claim to recover the sums paid to the organizer before the start of the tourist event. In addition, customers are entitled to return to the place of departure or to another place. If national law allows organizers to collect advances, the correct transposition of the directive takes place only if the amount of the advance payments is also secured.

Correct interpretation of Art. 7 should also grant the customers of the travel agencies with the cover of the cost of hotel accommodation in case of insolvency of the organizer. CJEU in the judgement of 14 May 1998 decided that if the customers of tourist agency, due to its insolvency, are obliged to cover the costs of hotel accommodation, the obligation of refunding these costs to the consumers is transferred to the insurer (Case C-364/96 Verein für Konsumenteninformation, European Court Reports 1998 I-02949).

In the judgement of December 1, 1998 (C-410/96, ECJ judgement in Ambra case, LEX No. 112553), CJEU stressed that the obligation to provide financial security to guarantee the return of clients to the country and the refund of money overpaid is a minimum level of customer protection that the Member States should provide. This hedge must not only exist but also be immediately available in case of necessity to pay for the return of the customers to the place of departure (Cybula, 2012, p. 83). For the scope of protection that tour operators have to offer, the circle of recipients of their offer is irrelevant. Even if the addressees of the tour offer are members of a narrow group of recipients, such protection should be ensured in such a way as to ensure that the objectives of the directive are adequately ensured (CJEU judgement in Rechberger's case of 15.6.1999, C-140/97, European Court Reports (1999), I-03499; Kunkiel-Kryńska, 2013, p. 37; Sekuła-Leleno, 2017, p. 131).

The actual reason of insolvency of the travel agency is insignificant for the sums of customers' claims (CJEU judgement of 16.2.2012, C-134/11 on Blödel-Pawlik case, unpublished). In the case in which the Court stated the position, the company declared bankruptcy before the planned date of journey, but it was apparent from the file that the trader did not intend to carry out the journey and that his behaviour was indicative of fraud. The Court in its decision of January 16, 2014 concluded that Art. 7 of Directive 90/314 must be interpreted as precluding national legislation which, in the event of insolvency of the travel organizer, does not lead to effective reimbursement to the customer of the full amount of money he paid and do not guarantee his return from the journey (Case C-430/13, Ilona Baradics et al. vs. QBE Insurance (Europe), published in Electronic Repositories).

New Directive 2015/2302 continues the ideas of the Directive 90/314. It is, however, based on the principle of maximum harmonization. This means that Member States have only a small margin of freedom in implementing its regulation. As a consequence, after the deadline for its transposition into national law, Member States will not be able to maintain regulations providing for a different level of legal protection (Kubiak-Cyrul, 2015, p. 21). 
As already stated above, Directive 2015/2302 primarily extends the scope of the protected entities envisaged in it. To date, this protection has been restricted to consumers (different Gnela, 2008, p. 52). The new directive clearly departs from this premise. As it states already in the preamble, other buyers of services should also be covered by it. Accordingly, the protection standard set out in Directive 2015/2302 should also apply to business travellers, including professionals or self-employed persons or other individuals, when the journey is not organized under a general contract. The consequence of the above is the departure from the term "consumer" in favour of a much more comprehensive formulation - "traveller". Traveller is, in turn, any person who wants to enter into an agreement or is entitled to travel on the basis of an agreement concluded within the scope of application of Directive 2015/2302 (Article 3 (6) of Directive 2015/2302).

This is a significant extension of the catalogue of beneficiaries of increased protection in the event of insolvency of the entrepreneur. The consumer's concept of Directive 90/314 is, in the opinion of the author, considerably narrower. Although there is no single general definition in EU legislation, it can be said that the consumer is usually perceived to be a natural person, undertaking activities unrelated to his or her professional or business activity (Gwoździcka-Piotrowska, 2008, pp. 66-67). In such a way, consumers are defined, for example, by Directive 2011/83 of the European Parliament and the Council (Directive of October 25, 2011, OJ $2011 \mathrm{~L}$ 304/64). The abstention by the EU legislator of the use of the word "consumer", together with the explicit declaration contained in the preamble, means that the scope of protection in the event of the insolvency of the trader is to be the same for both consumers and other persons, even if the trip was carried out in connection with professional activities. Consequently, the acquisition of a tourist event in connection with one's occupational or economic activity will not automatically result in the exclusion of the possibility of claiming the insolvency of the trader on the basis of provisions currently hitherto protecting only the consumer.

The new directive still leaves the Member States free to choose the form of financial collateral in the event of the insolvency of the trader. It also continues to impose the assumption of Directive 90/314 on the scope of the potential claims. Under the new regulations, Member States must provide a legal framework that will guarantee full protection in case of insolvency of the organizer. Organizers should have security in case of need to return all payments made by or on behalf of travellers and the return of travellers to the country. However, it should be possible to offer travellers a continuation of the event. Protection should be effective, which means primarily its immediate availability. Efficiency is also the appropriate level of security. This is to include predictable amounts of payments and, where appropriate, foreseeable costs of returning to the country (recitals 39-40 in the preamble to Directive 2015/2302).

The mentioned assumptions are materialized in art. 17 of the Directive (Sekuła-Leleno, 2017, 129-130). It stipulates that Member States shall ensure that entrepreneurs have collateral for the refund of all payments made by or on behalf of travellers, in so far as the services in question have not been provided due to the insolvency of the organizer. The hedge must be effective and include reasonably foreseeable costs. In the event that a traveller requests a refund for a non-performance of the service, the refund should be made immediately (Article 3 (16) of Directive 2015/2302).

Directive 2015/2302 also explicitly refers to the concept of redress for wasted holiday time, worked out under Directive 90/314 (Kuska-Żak, 2008, p. 169; Kolasiński, 2008, p. 247). Under the new directive, the traveller should have the right to have their problems solved while travelling, and if a substantial part of the contracted travel services 
cannot be provided, suitable alternative services should be offered. If these services are not offered within the time limit set by the traveller, he or she should be able to do it on his/her own and claim reimbursement of the necessary expenses. This situation will in particular be the case if an immediate remedial measure is required, for example when, due to the delay of the bus provided by the organizer, the traveller must use the taxi service to catch the flight. According to the preamble, travellers should be entitled to a reduced price, termination of the tour or compensation for damage. The latter should also cover non-pecuniary damage such as compensation for loss of pleasure from travel due to serious problems in the provision of adequate tourist services (recital 34 in the preamble to Directive 2015/2302). Referring to the stated assumptions, Art. 14 (2) of the new directive states that the traveller is entitled to receive compensation from the organizer for any damage he or she suffered, as a result of any incompatibility.

\section{Conclusions}

The primary goal of the EU directives regulating the tourism sector is to create a single market governed by equal legal rules connected with the provision of services and the protection of entities using the offer of tour operators. The need for maximum harmonization of regulations is particularly highlighted by the Directive 2015/2302.

The scope of claims for customers of insolvent organizers determined by both directives is extremely wide. The new directive repeats the current regulations in this area. This means that also after January 1, 2018 Member States will be obliged to create such legal framework that will guarantee the protection of all expenses incurred by travellers. These expenses include not only the refund of the cost of returning to the place of departure, but also any other fees that were paid in connection with an event which was not realized, fully or partially. The provisions of both directives do not envisage any exceptions in this regard. Additionally, the new legal regulation further extends the scope of entities subject to special protection. They are no longer "consumers", but "travellers". In the light of the explicit declaration of the EU legislator, travellers are also persons travelling in connection with their economic or professional activity.

The ruling in the Dillenkofer case leaves no doubt that shortcomings in the implementation of Directive 90/314 may be a sufficiently serious breach of EU law. This may lead to a Member State's liability for improper transposition of the directive (see Cases C-6/90 and C-9/90, Frankovich and Bonifaci, European Court Reports (1991). I-5357; C-91/92, Dori Faccini v. Recreb Srl, European Court Reports (1994), p. I-3325; Joined Cases C-46/93 and C-48/93 Brasserie du Pêcheur, European Court Reports (1996) I-1029; C-224/01, Köbler v. Austria, Judgement Report 2003 I-10239).

Article 7 of Directive 90/314 gives individuals the right, in the event of the insolvency of the organizer, to reimburse the amount paid to the organizer before the event and return to the place of departure or other place. If, as of the date of implementation of the directive, the customers did not receive the standard of protection provided for therein, the Member State shall be liable for that condition. This conclusion did not undermine the broad discretion of the Member States on the measures to ensure the implementation of the objectives of Directive 90/314 (Zawistowska, 2008, pp. 241-242; Brzezinski, 2010, pp. 119-120). These considerations are all the more true in the case of Directive 2015/2302, which aims at maximum harmonization of Member States.

This represents a serious challenge for the national legislature. As is clear from our experience, Poland has not always been able to meet the requirements imposed by the EU legislator on the proper transposition of Directive 90/314 (NSA judgement of 24.9.2014, II GSK 1157/13, Lex No 1572609; SN in Warsaw judgement of 28.5.2015, 
I ACa 1768/14, available at: http://www.orzeczenia.ms.gov.pl; SN judgement of 15.10.2015, I| CSK 836/14, OSNC 2016/10/119; Małysa-Ptak, 2015; Dolniak, 2017, p. 29; judgement of the District Court in Warsaw of 28.11.2014,

V Ca 594/14, available at: http://www.orzeczenia.ms.gov.com).

\section{Referenences}

Adam, R., Safjan, M., Tizzano, A. (eds.) (2014). Zarys prawa Unii Europejskiej. Warszawa: Wolters Kluwer Polska.

Brzeziński, P. (2010). Unijny obowiązek odmowy zastosowania przez sąd krajowy ustawy niezgodnej z dyrektywą Unii Europejskiej. Warszawa: Wolters Kluwer Polska.

Cybula, P. (2005). Formy zabezpieczenia finansowego organizatorów turystyki. Source: Lex

Cybula, P. (2012). Usługi turystyczne: Komentarz. Warszawa: Lex.

Cybula, P. (ed.) (2006). Prawo w praktyce biur podróży. Warszawa: LexisNexis.

Dolniak, P. (2017). Obowiązek zabezpieczenia finansowych interesów klientów biura podróży na wypadek niewypłacalności przedsiębiorcy- uwagi na tle nowelizacji ustawy o usługach turystycznych. Iustitia, 1.

Domańska, M. (2014). Implementacja dyrektyw unijnych przez sądy krajowe. Warszawa: Wolters Kluwer Polska.

Foltyn, M., Wierzbicki, P. (2016). Prace nad wdrożeniem nowej dyrektywy. Rynek Turystyczny, October.

Galster, J. (2006). Podstawy prawa Unii Europejskiej. Zarys wykładu. Toruń: Towarzystwo Naukowe Organizacji i Kierownictwa.

Gnela, B. (2008). Zakres podmiotowy przepisów ustawy o usługach turystycznych dotyczących ochrony klienta (konsumenta) a zakres podmiotowy umowy o imprezę turystyczna. In: P. Cybula, J. Raciborski (eds.), Turystyka a prawo. Aktualne problemy legislacyjne i konstrukcyjne. Sucha Beskidzka-Kraków: Wyższa Szkoła Turystyki i Ekologii w Suchej Beskidzkiej.

Gwoździcka-Piotrowska, M. (2008). Pojęcie klienta w ustawie o usługach turystycznych w świetle definicji konsumenta w prawie wspólnotowym i krajowym. In: P. Cybula, J. Raciborski (eds.), Turystyka a prawo. Aktualne problemy legislacyjne i konstrukcyjne. Sucha Beskidzka-Kraków: Wyższa Szkoła Turystyki i Ekologii w Suchej Beskidzkiej.

Kolasiński, M.K. (2008). Mechanizmy zapewniające realny wymiar odpowiedzialności odszkodowawczej biur podróży w prawie polskim w świetle standardów wspólnotowych. In: P. Cybula, J. Raciborski (eds.), Turystyka a prawo. Aktualne problemy legislacyjne i konstrukcyjne. Sucha Beskidzka-Kraków: Wyższa Szkoła Turystyki i Ekologii w Suchej Beskidzkiej.

Kubiak-Cyrul, A. (2015). Zakres stosowania nowej dyrektywy w sprawie imprez turystycznych i powiazanych usług turystycznych z perspektywy prawa polskiego. Studia Prawnicze. Rozprawy i Materiały, 2 (17), 19-34.

Kunkiel-Kryńska, A. (2013). Metody harmonizacji prawa konsumenckiego w Unii Europejskiej i ich wpływ na procesy implementacyjne w państwach członkowskich. Warszawa: Wolters Kluwer Polska.

Kuska-Żak, I. (2008). Odpowiedzialność organizatora turystyki za szkodę niemajątkową powstałą na skutek niewykonania lub nienależytego wykonania umowy o imprezę turystyczną. In: P. Cybula, J. Raciborski (eds.), Turystyka a prawo. Aktualne problemy legislacyjne i konstrukcyjne. Sucha Beskidzka-Kraków: Wyższa Szkoła Turystyki i Ekologii w Suchej Beskidzkiej.

Małysa-Ptak, K. (2015). Glosa do wyroku SN z dnia 15 października 2015 r., Il CSK 836/14. Zwrot kosztów powrotu do kraju. Source: Lex.

Nesterowicz, P. (2006). Prawo Turystyczne. Warszawa: Branta.

Sekuła-Leleno, M. (2017). Legitymacja procesowa czynna klientów niewypłacalnych biur podróży do samodzielnego dochodzenia roszczeń przed sadem. Glosa, 1.

Stefanicki, R. (2014). Glosa do postanowienia TS z dnia 16 stycznia 2014 r., C-430/13. Source: Lex.

Thorson, B. (2016). Individual Rights in EU Law. Berlin: Springer.

Walczak, R. (2007). Prawo turystyczne (z wybranymi elementami prawa cywilnego i handlowego) Akty prawne. Orzecznictwo. Pułtusk: Akademia Humanistyczna im. Aleksandra Gieysztora.

Wanat-Połeć, E.J., Sordyl, G.A. (2015). Wzmocnienie ochrony konsumentów niewypłacalnych touroperatorów w Polsce a koncepcja utworzenia Turystycznego Funduszu Gwarancyjnego. Annales Universitas Mariae Curie-Skłodowska Lublin - Polonia, XLIX, 4. 
Wróbel, A. (2005). Autonomia proceduralna państwa członkowskich. Zasada efektywności i zasada efektywnej ochrony sądowej w prawie Unii Europejskiej. Ruch Prawniczy, Ekonomiczny i Socjologiczny, 1 (LXVII).

Zawistowska, H. (2008). Systemy zabezpieczenia finansowego interesów nabywców imprez turystycznych na wypadek niewypłacalności ich organizatorów w państwach członkowskich UE. In: P. Cybula, J. Raciborski (eds.), Turystyka a prawo. Aktualne problemy legislacyjne i konstrukcyjne. Sucha Beskidzka-Kraków: Wyższa Szkoła Turystyki i Ekologii w Suchej Beskidzkiej.

Cite this article aS: Dolniak, P. (2018). Claims of travel agents in case of insolvency of the organizer of tourism in the light of EU directives. European Journal of Service Management, 3 (27/1), 63-69. DOI: 10.18276/ejsm.2018.27/1-08. 